\title{
Evaluation of the Method Based on Restriction Fragment Length Polymorphism Analysis as Simple Analysis Method of Lactic Acid Bacteria in Foods
}

\author{
Kunimasa Matsumoto', Kouya Shimada², Naoto Horinishi' ${ }^{1}$, Katsuji Watanabe ${ }^{1,2 *}$ \\ ${ }^{1}$ Department of Life, Environment and Materials Science, Graduate School of Engineering, Fukuoka Institute of \\ Technology, Fukuoka, Japan \\ ${ }^{2}$ Department of Life, Environment and Materials Science, Faculty of Engineering, Fukuoka Institute of \\ Technology, Fukuoka, Japan \\ Email: ${ }^{*}$ k-watanabe@fit.ac.jp
}

Received 23 January 2016; accepted 18 March 2016; published 21 March 2016

Copyright (C) 2016 by authors and Scientific Research Publishing Inc.

This work is licensed under the Creative Commons Attribution International License (CC BY). http://creativecommons.org/licenses/by/4.0/

(c) (i) Open Access

\section{Abstract}

Lactic acid bacteria have not only been used to produce various kinds of fermented food, but also used as probiotic products. As lactic acid bacterial group was consisted from diverse genera, a simple inspection method by which numbers and contained microorganisms could be automatically analyzed without any preliminary information was required to use them more effectively. In this manuscript, lactic acid bacterial groups in commercial products of kimuchi, komekouji-miso, and yoghurt were identified and enumerated by our newly developed method [1]-[3], to evaluate whether the method could be used as an inspection method of various food samples. In kimuchi, numerically dominant bacteria were Lactobacillus sakei, and $L$. casei $\left(1.4 \times 10^{4} \mathrm{MPN} \mathrm{g}^{-1}\right)$ and Leuconostoc spp. ( $\left.1.4 \times 10^{4} \mathrm{MPN}\right)$. In kouji-miso, numerically dominant bacteria was Bacillus spp. $\left(3 \times 10^{3} \mathrm{MPN}\right)$, which mainly included $B$. subtilis group and $B$. cereus group. Lactic acid bacteria such as Lactobacillus spp., or Lactococcus spp., included in the komekouji-miso, could be enumerated after 3 days incubation $\left(1.24 \times 10^{4} \mathrm{MPN}\right)$, but not detected after 7 days incubation. In yoghurt $A$ and $C$, Lactococcus lactis was detected as numerically dominant lactic acid bacteria $\left(3.0 \times 10^{5}\right.$ MPN). In yoghurt B, Lactobacillus spp., or Lactococcus spp., was detected not only by a culturebased method but also by an unculture-based method, although there was a difference between the both estimated numbers. The present results suggested that the method might become useful as a simple inspection method of food microorganisms, because time and labor of the analysis could be reduced by using an unculture-based method and MCE-202 MultiNA. In this study, Bifi-

\footnotetext{
"Corresponding author.
} 
dobacteriium spp. was not detected in B and C yoghurt, in spite of indicating their existence, and numbers of lactic acid bacteria were lower than the level of the daily product regulation, because 16S rDNA of Bifidobacteriium spp. might not be amplified by the used PCR condition. The PCR condition must be changed so as to amplify Bifidobacterium spp., before the method will be used as an inspection method for lactic acid bacteria.

\title{
Keywords
}

\author{
Multiple Enzyme Restriction Fragment Length Polymorphism Analysis, Most Probable Number \\ Method, Lactic Acid Bacteria, Komekouji-Miso, Kimuchi, Yoghurt
}

\section{Introduction}

Lactic acid bacteria have not only been used to produce various kinds of fermented food, but also used as probiotic products to exert a health benefit by eating living cells. There has recently been an increasing demand by the consumers and producers to use them more effectively. In the traditional fermentation process, various kinds of lactic acid bacteria were concerned with the fermentation process, which effected taste, texture, and flavor of the final products. As probiotics, their effect was suggested to modulate mucosal and systematic immunity [4], and improve the nutritional and microbial balance in the intestinal tract [5].

As lactic acid bacteria comprises the following genera, Streptcoccus spp., Bifidobacterium spp., Lactobacillus spp., Enterococcus spp., Lactococcus spp., and Leuconostoc spp., variety of culture-based and unculture-based techniques have been used not only to analyze their compositions in products [6], starter [7], and their natural source [8], but also to control fermentation process until now. As a probiotic product, they are often used as multispecies containing different probiotic species that belong to one or preferentially more genera. These methods were used to demonstrate the effect as probiotics [9] and investigate a mechanism of its functional effect [4].

Although most widely used unculture-based techniques, such as denaturing gradient gel electrophoresis (DGGE) [8]-[11] [12], or clone library sequencing [7] [13], provided relative abundance of each microbial groups, numbers of each microbial group remained unclear [14], and it took a lot of time and labor to provide the information of each lactic acid bacterial group. These faults seemed to disturb these methods to come into wide use. Especially as an inspection method, there was no method available by which numbers and contained microorganisms could be automatically analyzed without any preliminary information of sample and included microorganisms.

Until now, we had found a new affiliation method of microorganisms based on restriction fragment polymorphism analysis, and developed a system and method by which bacterial affiliations could systematically be completed [1]. By using isolated environmental bacteria, precision of bacterial affiliation had been evaluated [15]-[17]. Its combined use of the most probable number method (MPN) was found effective to provide numbers and taxonomies of each bacterial group without isolation in the former papers [2] [3]. In order to evaluate whether the method may become useful in a field of food microbiology, we have started to analyze microbial groups in various food samples by using this method. In this study, affiliation and enumeration of lactic acid bacterial group in commercial products, kimuchi, komekouji-miso, and yoghurt, by the method were presented.

\section{Materials and Methods}

\subsection{Samples}

We assumed that precision of the affiliation and enumeration of lactic acid bacteria in sample were depend on a ratio of lactic acid bacteria to the other bacterial groups in the sample. Komekouji-miso was selected as a representative sample including lower ratio of lactic acid bacterial group, kimuchi was selected as a representative sample including both lactic acid bacterial group and the other bacterial group, and yoghurt was selected as a representative sample including higher ratio of lactic acid bacterial group.

Commercial products of yoghurt A, yoghurt B, yoghurt C, komekouji-miso, and kimuchi directly imported from Korea were used. For MPN, serial 10 -fold dilutions $\left(10^{-2}\right.$ to $\left.10^{-7}\right)$ prepared from sample (1 g fresh wt.) were inoculated to test vials (3 replicates) including MRS medium (Difco, Sparks MD). As to komekouji-miso 
(A), microbial DNA in each vial was extracted after 3 days (MC3) and 7 days (MC7) of incubation at $30^{\circ} \mathrm{C}$. Microbial DNAs of the other samples (yoghurt A; YAC, yoghurt B; YBC, yoghurt YC; CC, kimuchi (KC)) were extracted after 3 days of the incubation. As yoghurt $\mathrm{B}$, microbial DNA was directly extracted without cultivation (YBU) after neutralization of $\mathrm{pH}$, and removal of casein. Each bacterial group was counted by MPN after the phylogenetic estimations.

\subsection{MERFLP of the Amplified $16 \mathrm{~S}$ rDNA}

Chromosomal DNAs of each MPN vials were prepared as described previously and purified by conventional methods. Amplification of 16S rDNA was according to the former study [15]-[17] using the V2 forward primer (41f), and the V6 reverse primer (1066r) [18] [19]. PCR product (10 $\mu$ l) was separately digested by each of 10 units of the restriction enzyme, Hae III or Hha I or Rsa I or Alu I (Takara Bio Co. Ltd. Shiga Japan) in Low salt buffer solution (10× Low salt buffer, Takara Bio Co. Ltd.). Fragment lengths were measured by microchip electrophoresis system (MCE-202 MultiNA; Shimadzu Co., Ltd. Kyoto Japan). The sample was diluted by de-ionized water ( 5 folds for Low salt buffer) before measuring by MCE-202.

\subsection{Theoretical Multiple Enzyme Restriction Fragment Length (MERFL) Database Used for the Estimation}

The newly constructed database was used for this research, which was edited using the method of Watanabe and Okuda [1] described previously [15]. For 41f/1066r primers, 30,844 post-amplification sequence files, which were consisted from 1379 bacterial genera, including uncultured and unidentified bacteria, were mainly reedited using small subunit rRNA files in RDP II release 9_61 [20] under 5-bases mismatches in the both in primer annealing sites. The number and diversity of the registered MERFLs in the database greatly increased from the former database, 4370 MERFLs, and 576 bacterial genera, using small subunit rRNA files in RDP II release 7.01 [21], and included the following lactic acid bacteria, 307 MERFLs of Streptcoccus spp., 68 MERFLs of Bifidobacterium spp., 416 MERFLs of Lactobacillus spp., 105 MERFLs of Enterococcus spp., 46 MERFLs of Lactococcus spp., and 31 MERFLs of Leuconostoc spp.

\subsection{Data Processing for Phylogenetic Estimation Using Multi-Template DNA and Phylogenetic Estimation}

As each MPN vials included multi-template DNAs originated from heterogeneous bacteria, most of the measured MERFL was the mixed MERFLs digested from the heterogeneous 16S rDNA. Whereas all the theoretical MERFLs were originated from the homogeneous 16S rDNA sequence, the measured MERFL digested from the homogeneous 16S rDNA was selected as described previously [2] [3].

The restriction fragments (RFs) with the highest relative mole concentration (ratio of fluorescent intensity to fragment size) were selected and used as the major RFs (represented as $\mathrm{H}$ in Table 1). After subtraction of the above the major RFs from the mixed heterogeneous RFs, RFs originated from the 2nd major gene were similarly selected and used for similarity search (represented as $\mathrm{M}$ in Table 1 ).

The similarity between the measured RFLP (A) and the theoretical RFLP (B) was calculated as described previously [1] [15]-[17] based on the pairwise distance $\left(D_{A B}\right)$ by the following equation; $D_{A B}=1-2 N_{A B} /\left(N_{A}+\right.$ $N_{B}$ ), where $N_{A}$ and $N_{B}$ were the numbers of fragments of each RFLs and $N_{A B}$ was the number of shared fragments that indicated same sizes within an allowance limit for measuring error according to Nei and $\mathrm{Li}$ [22]. The pairwise distance of the MERFLs $\left(D_{A B M E}\right)$ was an average of all the $D_{A B S}$ for used restriction enzymes. Similarity (\%) was $\left(1-D_{A B M E}\right) \times 100$ (Table 1$)$.

If the completely identical theoretical MERFL was not found by using all of the measured MERFL data, combinations of restriction enzymes used for the analysis was changed (Table 1) [15]-[17]. As to the measured MERFL which had no completely identical theoretical MERFL, the theoretical MERFL having the highest similarity to the measured MERFL was indicated in Table 1 [2] [3].

\subsection{Estimation of Numbers of Each Taxonomically Different Groups by the Most Probable Number Method}

Most probable numbers of each groups (A-F) were estimated for three-tube, three-decimal-dilution experiment 
Table 1. Affiliation of bacteria grown in serially diluted MRS medium by MERFLP ${ }^{\mathrm{a}}$.

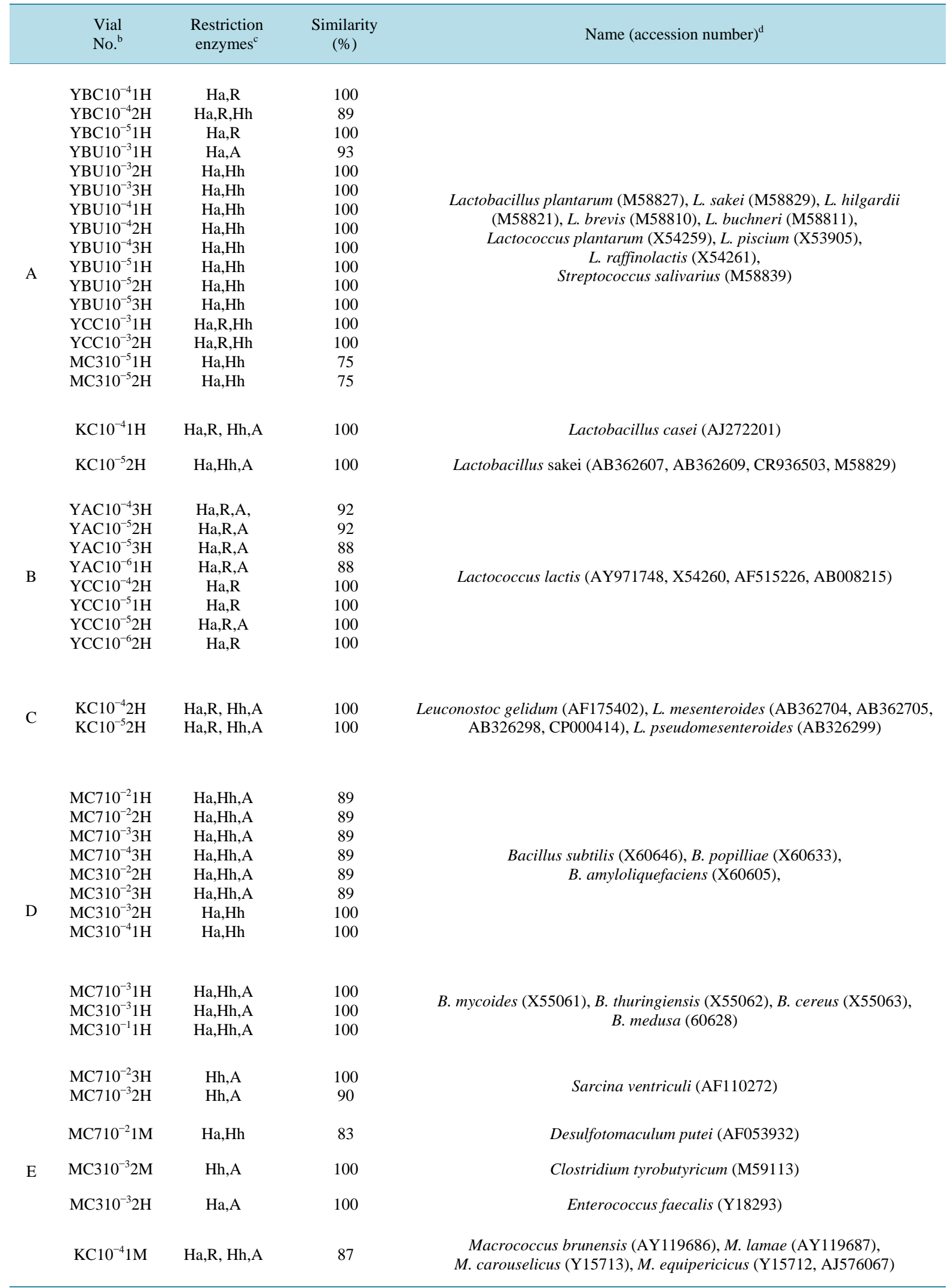




\section{Continued}

\begin{tabular}{|c|c|c|c|c|}
\hline \multirow{6}{*}{$\mathrm{F}$} & $\mathrm{MC} 710^{-2} 1 \mathrm{M}$ & Hh,A & 83 & Ralstonia gilardii (AF076645) \\
\hline & $\mathrm{MC} 710^{-4} 1 \mathrm{H}$ & Hh,A & 90 & Comamonas acidovorans (AB021417) \\
\hline & $\mathrm{MC} 310^{-2} 2 \mathrm{M}$ & Hh,A & 93 & Aquaspirillum gracile (AF078753) \\
\hline & $\mathrm{MC} 310^{-1} 3 \mathrm{H}$ & Hh,A & 100 & Coxiella burnetii (D89791) \\
\hline & YCC $10^{-5} 2 \mathrm{M}$ & $\mathrm{Ha}, \mathrm{Hh}$ & 100 & Desulfovibrio fairfieldensis (U42221) \\
\hline & $\begin{array}{l}\text { YAC } 10^{-3} 1 \mathrm{H} \\
\text { YAC } 10^{-5} 1 \mathrm{H}\end{array}$ & $\begin{array}{c}\text { Ha,Hh,R } \\
\text { Ha,R }\end{array}$ & $\begin{array}{c}83 \\
100\end{array}$ & Capnocytophaga sputigena (X67609), Porphyomonas gingivalis (L16429) \\
\hline $\begin{array}{l}\text { Grou } \\
\text { spp. ( } \\
\text { yogh } \\
\text { thod; } \\
\text { descr } \\
\text { repres } \\
\text { repre }\end{array}$ & $\begin{array}{l}\text { was based on } \\
\text { up D), the othe } \\
\text { llowed by pro } \\
\text { stand for cult } \\
\text { in materials a } \\
\text { number in } 5 \\
\text { from the } 2 \text { nd } \\
\text { For the measu } \\
\text { he RFLPs was } \\
\text { aving the high }\end{array}$ & $\begin{array}{l}\text { ation by N } \\
\text { nicutes (G } \\
\text { tems "A", } \\
\text { sed follow } \\
\text { thod. Exp } \\
\text { ates for th } \\
16 \mathrm{~S} \text { rDN } \\
\text { IERFLP w } \\
\text { nted with } \\
\text { nilarity wi }\end{array}$ & $\begin{array}{l}\text { vatior } \\
\text { vial } \\
\text { ion e } \\
\text { it com } \\
\text { ity as }\end{array}$ & $\begin{array}{l}\text { ria (Group A), Lactococcus lactis (Group B), Leuconostoc spp. (Group C), Bacillu } \\
\text { ve bacterial group (Group F). "The 1st letter in vial indicates samples; "Y" stands fo } \\
\text { ls for kouji-miso, and "K" stand for kimuchi. The next letter indicates extraction me } \\
\text { "3" stand for } 3 \text { days, and "7" stand for } 7 \text { days, and "U" stand for unculture-based a } \\
\text { represents the decimal dilution of the vial. The 2nd number of vial number (1 - } \\
\text { H of last letter represents MERFL originating from the major } 16 \mathrm{~S} \text { rDNA, and } \\
\text { used for similarity search; "Ha", "Hh", "R", and "A" stand for Hae III, Hha I, Rsa I } \\
\text { identical theoretical MERFLP, the theoretical MERFLP having the highest similarity } \\
\text { ed in the materials and method. "Species name (accession number) of the theoretica }\end{array}$ \\
\hline
\end{tabular}

(Table 2). MPN numbers and confidence limits shown in Table 2, which were calculated by the modified of de Man [23], were obtained using FDA’s Bacterial Analytical Manual [24].

\section{Results}

\subsection{Affiliation of Bacteria by MERFLP without Isolation}

Fifty two MERFLs in each MPN vials were differentiation into 8 groups based on the results of the affiliation and summarized in Table 1. The major group (Group A; 18 MERFLPs) contained Lactobacillus spp., such as $L$. plantarum, L. sakei, L. hilgardii, L. brevis, and L. buchneri, Lactococcus spp., such as L. plantarum, L. piscium, and L. raffinolactis, and Streptococcus salivarius (Table 1). Although, MERFL of KC10 ${ }^{-3} 1 \mathrm{H}$ was completely identical with that of Lactobacillus casei (AJ272201) and that of $\mathrm{KC} 10^{-4} 2 \mathrm{H}$ was completely identical with that of Lactobacillus sakei (AB362607, AB362609, CR936503, M58829), they were included in this group (Table 1). The other lactic acid bacterial group were affiliated to be Lactococcus lactis (Group B; 8 MERFLs), and Leuconostoc spp., such as L. gelidum, L.mesenteroides, and Lpesudomesenterides (Group C; 2 MERFLs) (Table 1). The $2^{\text {nd }}$ major group (Group D; 11 MERFLPs) contained Bacillus spp., which were further differentiated into the following 3 subgroups, B. subtilis group, B. licheniformis/sphaericus, and B. cereus group (Table 1 ). The other Firmicutes (Group E; 6 MERFLs) and gram negative bacterial group (Group F; 8MERFLPs) were also existed (Table 1).

In the major MERFL, represented as " $H$ " of last letter, ratio of the MERFLs having $100 \%$ similarity to the corresponding theoretical MERFLs (62.5\%) was almost as same as that of the former study (62.9\%) [3] and lower than that of the previous study (90.5\%) [2]. This might be caused from a difference of used incubation media as the following; As TSA medium used in this study was not a selective medium, more diverse microorganisms were proliferated in the each MPN vials than that used in the former study, which made it more difficult to select the MERFLP digested from the homogeneous 16S rDNA among the mixed MERFL.

\subsection{Enumeration of Each Bacterial Groups by MPN}

The numerically dominant bacteria in komekouji-miso after 3 days (AC3) and 7 days (AC7) cultivation were Bacillus spp. (Group D), which included $B$. subtilis group and B. cereus group $\left(3 \times 10^{3}\right.$ MPN in the both AC7 and AC3 (Table 2, Figure 1). Although their similarity to the corresponding theoretical MERFLP (75\%) was lower than the others (Table 1), Group A lactic acid bacteria was only detected in AC3 $\left(1.2 \times 10^{3}\right.$ MPN) (Table 2, Figure 1). There was not so large difference in numbers of the group E between AC7 and AC3 $\left(0.15 \times 10^{3}\right.$ MPN in AC7 and $0.22 \times 10^{3} \mathrm{MPN}$ in AC3), and numbers of group D were $0.14 \times 10^{3} \mathrm{MPN}$ in AC7 and $0.014 \times$ $10^{3} \mathrm{MPN}$ in AC3 (Table 2, Figure 1). 
Table 2. Most probable numbers of each groups (A-F) in komekouji-miso (AC3, AC7) and kimuchi (KC) and 5\% confidence limits obtained using FDA’s Bacterial Analytical Manual [24]. Group B was not detected.

\begin{tabular}{|c|c|c|c|c|c|c|c|c|c|c|}
\hline & \multicolumn{2}{|c|}{ Group A } & \multicolumn{2}{|c|}{ Group C } & \multicolumn{2}{|c|}{ Group D } & \multicolumn{2}{|c|}{ Group E } & \multicolumn{2}{|c|}{ Group F } \\
\hline & $\begin{array}{l}\text { Three } \\
\text { dilution }\end{array}$ & $\begin{array}{l}\times 10^{4} \\
\text { MPN }\end{array}$ & $\begin{array}{l}\text { Three } \\
\text { dilution }\end{array}$ & $\begin{array}{l}\times 10^{4} \\
\text { MPN }\end{array}$ & $\begin{array}{c}\text { Three } \\
\text { dilution }\end{array}$ & $\begin{array}{l}\times 10^{4} \\
\text { MPN }\end{array}$ & $\begin{array}{l}\text { Three } \\
\text { dilution }\end{array}$ & $\begin{array}{l}\times 10^{4} \\
\text { MPN }\end{array}$ & $\begin{array}{l}\text { Three } \\
\text { dilution }\end{array}$ & $\times 10^{4} \mathrm{MPN}$ \\
\hline & Score & $5 \%$ limits & Score & $5 \%$ limits & Score & $5 \%$ limits & Score & $5 \%$ limits & Score & $5 \%$ limits \\
\hline \multirow[b]{2}{*}{ AC7 } & & & & & $10^{-3} 10^{-4} 10^{-5}$ & 0.30 & $10^{-2} 10^{-3} 10^{-4}$ & 0.0148 & $10^{-2} 10^{-3} 10^{-4}$ & 0.0144 \\
\hline & nd & & nd & & $2-1-0$ & $\begin{array}{l}0.074 / \\
0.82\end{array}$ & $1-1-0$ & $\begin{array}{c}0.0026 / \\
0.04\end{array}$ & $1-0-1$ & $\begin{array}{c}0.0026 / \\
0.036\end{array}$ \\
\hline \multirow[b]{2}{*}{ AC3 } & $10^{-4} 10^{-5} 10^{-6}$ & 1.24 & & & $10^{-3} 10^{-4} 10^{-5}$ & 0.3 & $10^{-2} 10^{-3} 10^{-4}$ & 0.022 & $10^{-1} 10^{-2} 10^{-3}$ & 0.00144 \\
\hline & $0-2-0$ & $0.24 / 3.6$ & nd & & $2-1-0$ & $\begin{array}{c}0.0074 / \\
0.84\end{array}$ & $1-2-0$ & $\begin{array}{l}0.007 / \\
0.084\end{array}$ & $1-1-0$ & $\begin{array}{c}0.00026 / \\
0.004\end{array}$ \\
\hline \multirow[b]{2}{*}{ KC } & $10^{-4} 10^{-5} 10^{-6}$ & 1.44 & $10^{-4} 10^{-5} 10^{-6}$ & 1.44 & & & $10^{-4} 10^{-5} 10^{-6}$ & 0.06 & & \\
\hline & $1-1-0$ & $0.26 / 4.0$ & $1-1-0$ & $\begin{array}{c}0.26 / \\
4.0\end{array}$ & nd & & $0-1-0$ & $\begin{array}{c}0.003 / \\
0.22\end{array}$ & nd & \\
\hline
\end{tabular}

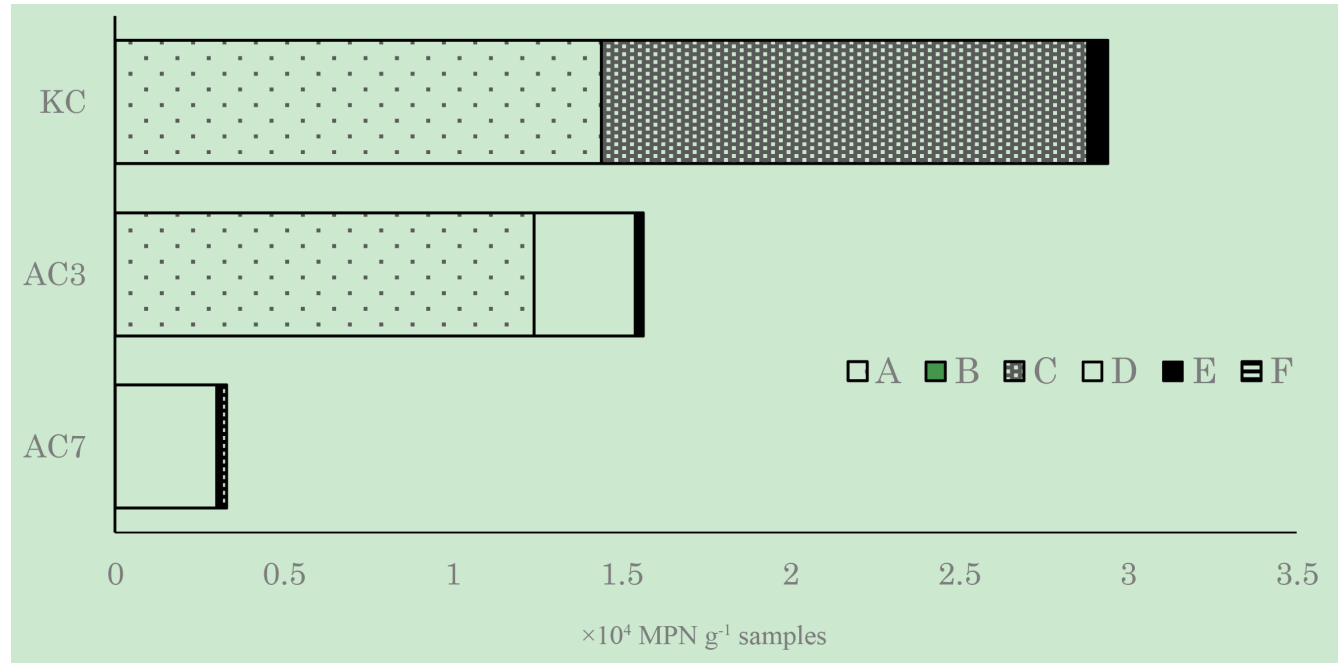

Figure 1. Numbers of bacterial groups estimated by MPN and MERFLP in kimuchi (KC), and kouji-miso after 3days incubation (AC3), and 7 days incubation (AC7). Number of Lactobacillus spp. and Lactococcus spp. (Group A; 5 ), Lactococcus lactis (Group B; $\square$ ), Leuconostoc spp., (Group C; 国), Bacillus spp. (Group D; $\square$ ), the other Firmicutes (Group E; $\square$ ), and gram negative bacteria (Group F; 目) were presented.

The numerically dominant lactic acid bacteria in kimuchi (KC) after 3 day cultivation were Group A (1.4 $\times$ $10^{4} \mathrm{MPN}$, Lactobacillus sakei, and L. casei,) and Group C (1.4 × 10 $0^{4} \mathrm{MPN}$, Leuconostoc spp.), and lower number of the other Firmicutes $\left(6 \times 10^{2}\right.$ MPN, Macrococcus spp.) was included (Table 2, Figure 1).

Lactococcus lactis (Group B) was the numerically dominant lactic acid bacteria (3 $310^{5}$ MPN/g product) in yoghurt A (YAC) and yoghurt C (YCC), which also contained lower numbers of gram negative bacterial group (Group F; $6 \times 10^{3}$ MPN (2\%) in YCC and $1.44 \times 10^{3}$ MPN (0.48\%) in YAC), and YCC contained a trace number of the other lactic acid bacteria (Group A; $1.24 \times 10^{2}$ MPN 0.04\%) (Table 3, Figure 2). In the both cultured (YBC) and uncultured (YBU) yoghurt B, the lactic acid bacteria of group A was solely detected (Table 3, Figure 2). These result indicated that yoghurt of commercial product included mainly lactic acid bacterial group. The number of YBU, which used the DNA directly extracted from the yoghurt $\mathrm{B}$, was 8 times higher than that of YBC, used the DNA extracted after incubation in TSA medium (Table 3, Figure 2).

\section{Discussion}

During miso fermentation, $B$. subtilis was reported to present at $10^{4}-10^{6} \mathrm{CFU} \mathrm{g}^{-1}$, and decreased to under $10^{4}$ $10^{5} \mathrm{CFU} \mathrm{g}^{-1}$ [19] [20]. The number of Bacillus spp., in the both AC7 and AC3 (3 $\times 10^{3} \mathrm{MPN} \mathrm{g}^{-1}$, Table 2), 


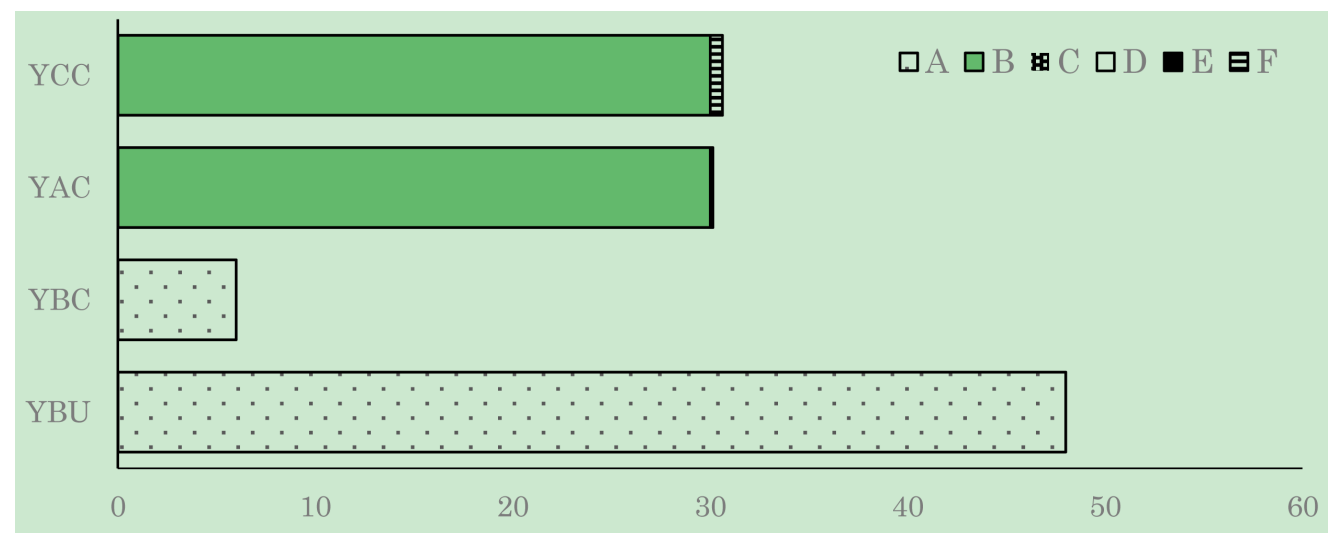

Figure 2. Numbers of bacterial groups estimated by MPN and MERFLP in yogurt C (YCC), yogurt A (YAC), and yogurt B (YBC) by culture-based method, and that of yogurt $\mathrm{B}$ (YBU) by unculture-based mehod. kouji-miso after 3days incubation (AC3), and 7 days incubation (AC7). Number of Lactobacillus spp. and Lactococcus spp. (Group A; 9 ), Lactococcus lactis (Group B; $\square$ ), Leuconostoc spp., (Group C; 面), Bacillus spp. (Group D; $\square$ ), the other Firmicutes (Group E; $\square$ ), and gram negative bacteria (GroupF; 且) were presented.

Table 3. Most probable numbers of each groups (A-F) in yoghurt (YA, YB, YC) and 5\% confidence limits obtained using FDA’s Bacterial Analytical Manual [24]. Group C, D, and E were not detected.

\begin{tabular}{ccccccc}
\hline & \multicolumn{2}{c}{ Group A } & \multicolumn{2}{c}{ Group B } & \multicolumn{2}{c}{ Group F } \\
\cline { 2 - 7 } Samples & $\begin{array}{c}\text { Three } \\
\text { dilution }\end{array}$ & $\times 10^{4}$ MPN & $\begin{array}{c}\text { Three } \\
\text { dilution }\end{array}$ & $\times 10^{4}$ MPN & $\begin{array}{c}\text { Three } \\
\text { dilution }\end{array}$ & $\times 10^{4}$ MPN \\
\cline { 2 - 7 } & Score & $5 \%$ limits & Score & $5 \%$ limits & Score & $5 \%$ limits \\
yCC & $10^{-2} 10^{-3} 10^{-4}$ & 0.0124 & $10^{-5} 10^{-6} 10^{-7}$ & 30 & $10^{-4} 10^{-5} 10^{-6}$ & 0.6 \\
& $0-2-0$ & $0.0024 / 0.036$ & $2-1-0$ & $7.4 / 84$ & $0-1-0$ & $0.03 / 2.2$ \\
YAC & & & $10^{-5} 10^{-6} 10^{-7}$ & 30 & $10^{-3} 10^{-4} 10^{-5}$ & 0.144 \\
& nd & & $2-1-0$ & $7.4 / 84$ & $1-0-1$ & $0.026 / 0.36$ \\
YBC & $10^{-4} 10^{-5} 10^{-6}$ & 6.0 & & & & nd \\
YBU & $2-1-0$ & $0.074 / 8.4$ & nd & & & nd \\
\hline
\end{tabular}

which included B. subtilis group (Table 1), were within an average of commercial products. Lactic acid bacteria of group A, which included miso fermentation bacteria of Lactobacillus plantarum (MC310 $\left.0^{-5} 1 \mathrm{H}, \mathrm{MC} 310^{-5} 2 \mathrm{H}\right)$, and Enterococcus faecalis (MC310 $\left.{ }^{-3} 2 \mathrm{H}\right)$ [20] [21], were only detected in AC3 but not in AC7 (Table 1). PCR amplification of lactic acid bacteria in AC7 was inhibited by the Bacillus spp. proliferated during the longer incubation period of AC7, which also inhibited the precise affiliation (75\%) of lactic acid bacteria of group A (MC310 ${ }^{-5} 1 \mathrm{H}$ and $\mathrm{MC}_{10}{ }^{-5} 2 \mathrm{H}$ ) in AC3 (Table 1).

Leuconostoc spp., and Lactobacillus sakei were reported to be dominant lactic acid bacteria during kimuchi fermentation [21]. As Bacillus spp. was not included in the sample, lactic acid bacteria $\left(\mathrm{KC} 10^{-4} 1 \mathrm{H}, \mathrm{KC} 10^{-5} 2 \mathrm{H}\right.$, $\mathrm{KC} 10^{-4} 2 \mathrm{H}, \mathrm{KC} 10^{-5} 2 \mathrm{H}$ ) was affiliated precisely (100\%) (Table 1).

Most of bacteria included in the yoghurts (YCC, YAC, YBC, and YBU) were lactic acid bacteria and no- $B a-$ cillus spp. detected (Table 3, Figure 2), which resulted in more precise affiliations as the following; with respect to yoghurts (YCC, YAC, YBC, and YBU), a ratio of $100 \%$ similarity to those of the corresponding theoretical MERFL increased to 75\% from 62.9\% (total samples) (Table 1).

\section{Conclusions}

The total number of included bacterial group in komekouji-miso (MC7 and 3) and kimuchi (KC) was lower than 
that of Japanese food sanitary regulations where numbers of microorganisms included in commercial product must be lower than $10^{5}$ cells/g (Table 2), and most of the detected bacteria were originated from their fermentation process (Table 2).

However, the total number of lactic acid bacteria, YCC; $3.06 \times 10^{5} \mathrm{MPN} \mathrm{g}^{-1}$, YAC; $3.01 \times 10^{5} \mathrm{MPN}$, YBC; $0.6 \times 10^{5}$ MPN, YBU; $4.8 \times 10^{5} \mathrm{MPN}$, was lower than that of Japanese daily product regulation, which indicated that daily product including lactic acid bacteria or yeast over $10^{7} \mathrm{cell} / \mathrm{mL}$ could be treated as fermented daily product (Table 3, Figure 2). Bifidobacteriium spp. was not detected in all the yoghurt tested, in spite that Bifidobacterium longum was indicated to be included in yoghurt B as the major lactic acid bacteria, and the following lactic acid bacteria, Bifidobacterium lactis, Lactobacillus delbrueckii, L. helveticus, and Streptococcus thermophilus were indicated to be included in yoghurt C. Absence of Bifidobacterium and lower number of lactic acid bacteria were caused from the used PCR condition; recent research indicated that 16S rDNAs of some of the Actinobacteria, especially Bifidobacteriium spp., and Firmicutes were not amplified by the used PCR condition, because the annealing site of some 16Sr DNAs of such the Actinobacteria and Firmicutes included over 3 miss-matched bases to this primer by using computer simulation (unpublished results). We concluded a difference between estimated number using directly extracted DNA and that using DNA extracted after incubation as follows; during incubation, Bifidobacterium spp., which could not be amplified by the PCR condition, might proliferated preferentially to the group A of lactic acid bacterial group, which might decrease relative DNA mole ratio of Group A and inhibited PCR amplification. The detection of Bifidobacteriium spp. by a new PCR condition including newly designed PCR primer for these bacteria will be presented in the following manuscript.

Until now the method had been used as a culture-based method because accurate affiliation was impossible for sample having huge microbial diversity and large amount of PCR inhibiting substance such as soil sample [2] [25] [26] and manure [3]. As precise affiliation mainly depended on whether the measured MERFLP digested from the homogeneous 16S rDNA could precisely be selected among the mixed MERFLs digested from the heterogeneous 16S rDNA, microbial diversity and concentration of PCR inhibiting substance had to be decreased by selective incubation for such the samples [2]. The present result indicated that a sample having lower microbial diversity and having no PCR inhibition substance, such as yoghurt, was found to be analyzed without cultivation.

Compared to the next-generation method such as pyro-sequencing, by which each bacterial number was estimated by quantitative PCR from relative abundance of dominant microorganism after affiliations of all the microorganisms [27] [28]. Our method provided information of the most dominant microorganisms preferentially to the minor one more simply and rapidly. As reliable affiliations of all the bacteria might be difficult by our method, our method might not be suitable for pure research purpose, but suitable as an inspection method due to its lower running cost and simplicity. Microchip electrophoresis system (MCE-202 MultiNA) was found suitable for this usage because 95 samples were automatically analyzed within a short time, and unculture-based method added an advantage to reduce a time required for analysis. Compared to the traditional culture based method, this method provided information of both affiliations and numbers of bacterial group at the same time; i.e., we could know what kinds and how many lactic acids bacteria were included in the sample by using the method alone.

The availability as evaluation method for the other microbial groups, such as multi-drug resistant bacteria, bacteria causing food poisoning, bacteria having special functions, eukaryote, a precision of the affiliation, and validation of enumeration of each microbial group will be described in the following manuscripts.

\section{Acknowledgements}

We thank Mr. S. Hirai, Mr. A. Masaki, Mr. Y. Tone, and Miss. R. Ito, the former undergraduate students, for analysis of samples. We thank Mr. Y. Sogabe, Global application Center, Shimadzu Co. for variable suggestion and support for MultiNA. We thank Prof. H. Tamura, and Dr. A. Hosoda, Meijyo University, Dr. H. Yosikawa, the former Prof. of Fukuoka Institute of Technology for their suggestions and encouragements during this work.

\section{References}

[1] Watanabe, K. and Okuda, M. (2003) Method and System for Searching for Relationships between Base Sequences in Genes. Japanese Patent 3431135, US Patent, 7006924.

[2] Watanabe, K., Horinishi, N. and Matumoto, K. (2015) Antibiotic-Resistant Bacterial Group in Field Soil Evaluated by 
a Newly Developed Method Based on Restriction Fragment Length Polymorphism Analysis. Advances in Microbiology, 5, 807-816. http://dx.doi.org/10.4236/aim.2015.512085

[3] Watanabe, K., Horinishi, N., Matumoto, K., Tanaka, A and Yakushido, K. (2015) Bacterial Groups Concerned with Maturing Process in Manure Production Analyzed By a Method Based on Restriction Fragment Length Polymorphism Analysis. Advances in Microbiology, 5, 832-841. http://dx.doi.org/10.4236/aim.2015.513088

[4] Bajaj, B.K., Claes, I.J.J. and Lebber, S. (2015) Functional Mechanisms of Probiotics. Journal of Microbiology, Biotechnology and Food Sciences, 4, 321-327. http://dx.doi.org/10.15414/jmbfs.2015.4.4.321-327

[5] Park, Y.H., Kim, J.G., Shin, Y.W., Kim, H.S., Kim, Y.J., Chun, T., Kim, S.H. and Whang, K.Y. (2008) Effects of Lactobacillus acidophilus 43121 and a Mixture of Lactobacillus casei and Bifidobacterium longum on the Serum Cholesterol Level and Fecal Sterol Excretion in Hypercholesterolemia-Induced Pigs. Bioscience Biotechnology and Biochemistry, 72, 595-600. http://dx.doi.org/10.1271/bbb.70581

[6] Skelin, A., Mrkonjic, M., Majhenic, A.C., Redzepovic, S., Samarzija, D. and Matijasic, B.B. (2012) Phenotypic and Genotypic Characterization of Indigenous Lactobacillus Community from Traditional Istrian Ewe's Cheese. Food Technology and Biotechnology, 50, 362-370.

[7] Pavunc, A.L., Beganovic, J., Kos, B., Uroic, K., Blazic, M. and Suskovic, J. (2012) Characterization and Application of Autochthonous Starter Cultures for Fresh Cheese Production. Food Technology and Biotechnology, 50, 141-151.

[8] Hagi, T., Kabayashi, M. and Nomura, M. (2010) Molecular-Based Analysis of Changes in Indigenous Milk Microflora during the Grazing Period. Bioscience Biotechnology and Biochemistry, 74, 484-487. http://dx.doi.org/10.1271/bbb.90470

[9] Gracia-Albiach, R., Jose, M., Felipe, P.D., Angulo, S., Morosini, M.I., Bravo, D., Baquero, F. and Campo, R.D. (2008) Molecular analysis of Yogurt Containing Lactobacillus delbrueckii subsp. bulgaricus and Streptococcus thermophilus in Human Intestinal Microbiota. American Journal of Clinical Nutrition, 87, 91-96.

[10] Onda, T., Yanagida, F., Tsuji, M., Shinohara T. and Yokotsuka, K. (2003) Time Series Analysis of Aerobic Bacterial Flora during Miso Fermentation. Letters in Applied Microbiology, 37, 162-168. http://dx.doi.org/10.1046/j.1472-765X.2003.01371.x

[11] Onda, T., Yanagida, F., Uchimura, T., Tsuji, M., Shinohara, T., Ogino, S. and Yokotsuka, K. (2003) Analysis of Lactic Acid Bacterial Flora during Miso Fermentation, Food Science and Technology Research, 9, 17-24. http://dx.doi.org/10.3136/fstr.9.17

[12] Ercolini, D. (2004) PCR-DGGE Fingerprinting: Novel Strategies for Detection of Microbes in Food. Journal of Microbiological Methods, 56, 297-314. http://dx.doi.org/10.1016/j.mimet.2003.11.006

[13] Kim, M. and Chun, J.B. (2005) Bacterial Community Structure in Kimchi, a Korean Fermented Vegetable Food, as Revealed by 16S rRNA Gene Analysis. International Journal of Food Microbiology, 103, 91-96. http://dx.doi.org/10.1016/j.ijfoodmicro.2004.11.030

[14] Neilson, J.W., Jordan, F.L. and Maier, R.M. (2013) Analysis of Artifacts Suggests DGGE Should Not Be Used for Quantitative Diversity Analysis. Journal of Microbiological Methods, 92, 256-263. http://dx.doi.org/10.1016/j.mimet.2012.12.021

[15] Watanabe, K., Okuda, M. and Koga, N. (2008) A Newly Developed System Based on Multiple Enzyme Restriction Fragment Length Polymorphism-An Application to Proteolytic Bacterial Flora Analysis. Soil Science and Plant Nutrition, 54, 204-215.

[16] Watanabe, K. (2008) Application of Multiple Enzyme Restriction Fragment Length Polymorphism Analysis and Microchip Electrophoresis for Estimation of Antibiotic-Tolerant Bacterial Group. Journal of Pesticide Science, 33, 249260. http://dx.doi.org/10.1584/jpestics.G08-04

[17] Watanabe, K. and Koga, N. (2009) Use of a Microchip Electrophoresis System for Estimation of Bacterial Phylogeny and Analysis of $\mathrm{NO}_{3}^{-}$Reducing Bacterial Flora in Field Soils. Bioscience Biotechnology and Biochemistry, 73, 479488. http://dx.doi.org/10.1271/bbb.70712

[18] Schewieger, F. and Tebbe, C.C. (1998) A New Approach To Utilize PCR-Single-Strand-Conformation Polymorphism for 16S rRNA Gene-Based Microbial Community Analysis Applied and Environmental Microbiology, 64, 4870-4876.

[19] Weidner, S., Arnold, W. and Puhler, A. (1996) Diversity of Uncultured Microorganisms Associated with the Seagrass Halophila stipulacea Estimated by Restriction Fragment Length Polymorphism Analysis Of PCR-Amplified 16S rRNA Genes. Applied and Environmental Microbiology, 62, 766-771.

[20] Maidak, B.L., Cole, J.R., Parker, C.T., Garrity, G.M., Larsen, N., Li, B., Lilburn, T.G., McCaughey, M. J., Olsen, G.J., Overbeek, R., Pramanik, S., Schmidt, T.M., Tiedje, J.M. and Woese, C.R. (1999) A New Version of the RDP (Ribosomal Database Project). Nucleic Acids Research, 27, 171-173. http://dx.doi.org/10.1093/nar/27.1.171

[21] Cole, J.R., Chai, B., Farris, R., Wang, Q., Kulam-Syed-Mohideen, A.S., McGarrell, D.M., Bandela, A.M., Cardenas, E., 
Garrity, G.M. and Tiedje, J.M. (2007) The Ribosomal Database Project (RDP-II): Introducing myRDP Space and Quality Controlled Public Data. Nucleic Acids Research, 35, D169-D172. http://dx.doi.org/10.1093/nar/gkl889

[22] Nei, M. and Li, W.H. (1979) Mathematical Model for Studying Genetic Variation in Terms of Restriction Endonucleases. Proceedings of the National Academy of Sciences of the United States of America, 76, 5269-5273. http://dx.doi.org/10.1073/pnas.76.10.5269

[23] Blodgett, R. (2010) FDA, Bacterial Analytical Manual, Appendix 2 Most Probable Number from Serial Dilutions. http://www.fda.gov/Food/FoodScienceResearch/LaboratoryMethods/ucm109656.htm

[24] de Man, J.C.(1983) MPN Tables, Corrected. European Journal of Applied Microbiology and Biotechnology, 17, 301305. http://dx.doi.org/10.1007/BF00508025

[25] Tebbe, C.C. and Vahjen, W. (1993) Interference of Humic Acids and DNA Extracted Directly from Soil in Detection and Transformation of Recombinant DNA from Bacteria and a Yeast. Applied and Environmental Microbiology, 59, 2657-2665.

[26] Watanabe, K. (2009) Detection of Protease Genes In Field Soil Applied with Liquid Livestock Feces and Speculation on Their Function and Origin. Soil Science and Plant Nutrition, 55, 42-52.

[27] Kiyohara, M., Koyanagi, T., Matsui, H., Yamamoto, K., Take, H., Katsuyama, Y., Tsuji, A., Miyamae, H., Kondo, T., Nakamura, S., Katayama, T. and Kumakai, H. (2012) Changes in Microbiota Population during Fermentation of Narezushi as Revealed by Pyrosequencing Analysis. Bioscience Biotechnology and Biochemistry, 76, 48-52. http://dx.doi.org/10.1271/bbb.110424

[28] Koyanagi, T., Nakagawa, A., Kiyohara, M., Matsui, H., Yamamoto, K., Barla, F., Take, H., Katsuyama, Y., Tsuji, A., Shijimaya, M., Nakamura, S., Minami, H., Enomoto, T., Katayama, T. and Kumakai, H. (2013) Pyrosequencing Analysis of Microbiota in Kaburazushi, a Traditional Medieval Suchi in Japan. Bioscience Biotechnology and Biochemistry, 77, 2215-2130. http://dx.doi.org/10.1271/bbb.130550 